\title{
LEVEL II SCOUR ANALYSIS FOR BRIDGE 49 (BETHTH00790049) on TOWN HIGHWAY 79, crossing LOCUST CREEK, BETHEL, VERMONT
}

U.S. Geological Survey Open-File Report 96-303

Prepared in cooperation with

VERMONT AGENCY OF TRANSPORTATION and

FEDERAL HIGHWAY ADMINISTRATION 


\section{LEVEL II SCOUR ANALYSIS FOR BRIDGE 49 (BETHTH00790049) on TOWN HIGHWAY 79, crossing LOCUST CREEK, BETHEL, VERMONT By MICHAEL A. IVANOFF and SCOTT A. OLSON}

U.S. Geological Survey Open-File Report 96-303

Prepared in cooperation with

VERMONT AGENCY OF TRANSPORTATION and

FEDERAL HIGHWAY ADMINISTRATION

Pembroke, New Hampshire 


\title{
U.S. DEPARTMENT OF THE INTERIOR BRUCE BABBITT, Secretary
}

\author{
U.S. GEOLOGICAL SURVEY \\ Gordon P. Eaton, Director
}

For additional information write to:

District Chief

U.S. Geological Survey 361 Commerce Way

Pembroke, NH 03275
Copies of this report may be purchased from:

U.S. Geological Survey Earth Science Information Center Open-File Reports Section Box 25286, MS 517 Federal Center

Denver, CO 80225 


\section{CONTENTS}

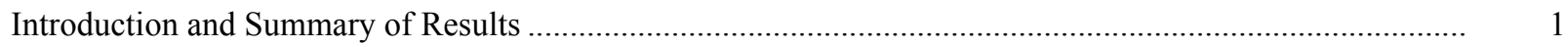

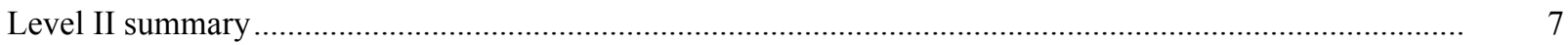

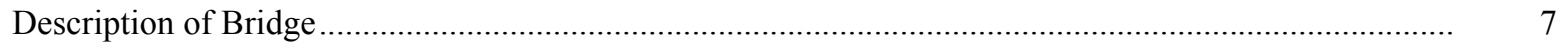

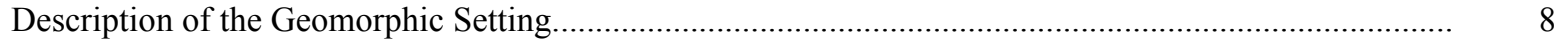

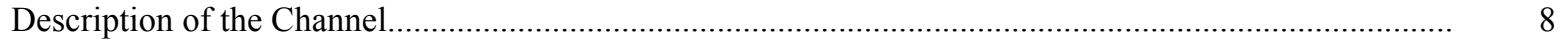

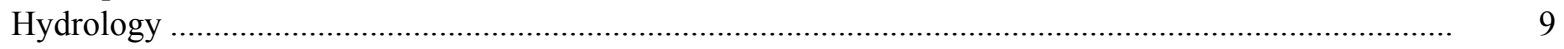

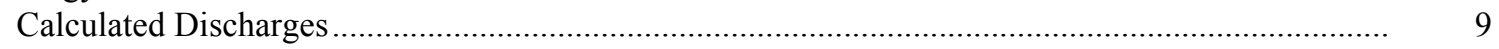

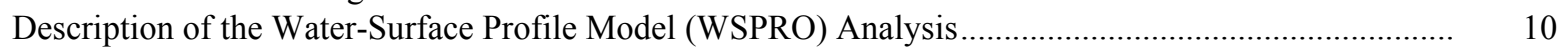

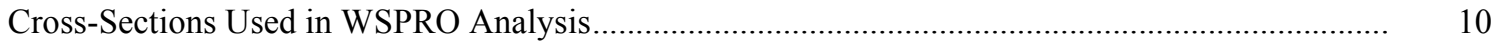

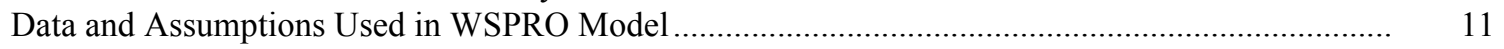

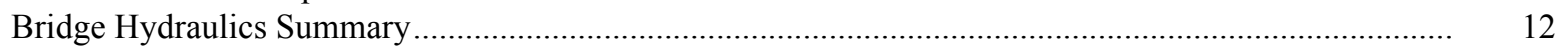

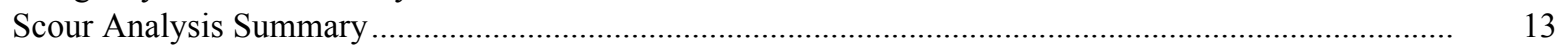

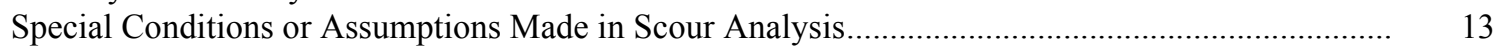

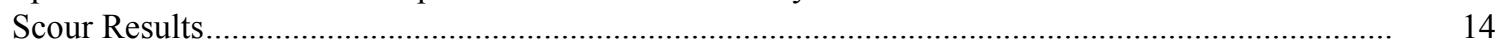

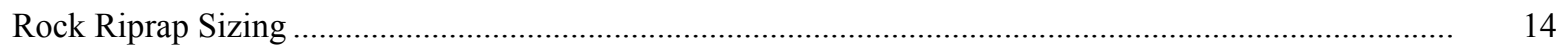

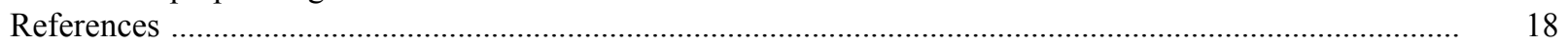

Appendixes:

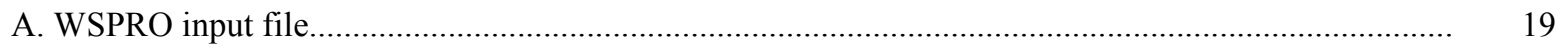

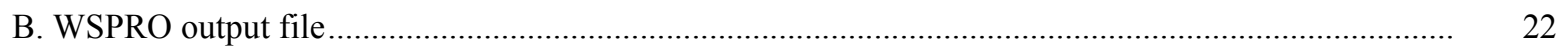

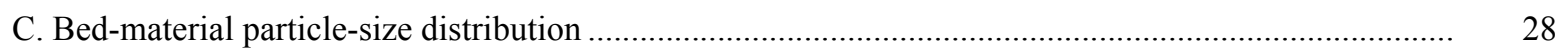

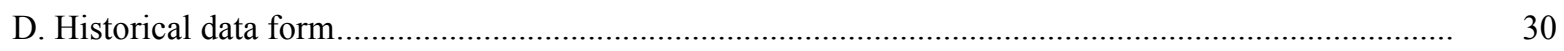

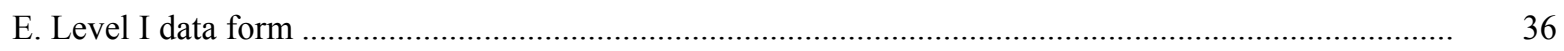

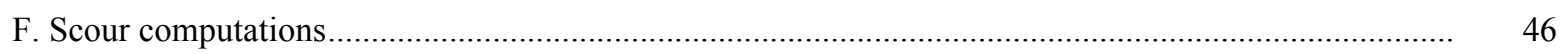

\section{FIGURES}

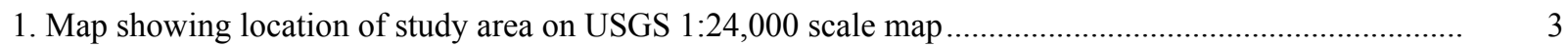

2. Map showing location of study area on Vermont Agency of Transportation town

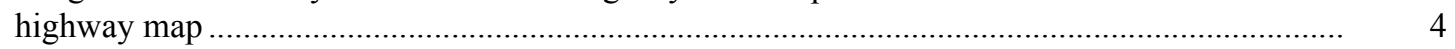

3. Structure BETHTH00790049 viewed from upstream (September 26, 1994) ..........................................

4. Downstream channel viewed from structure BETHTH00790049 (September 26, 1994) ........................ 5

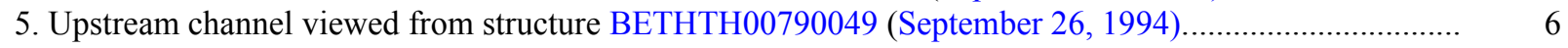

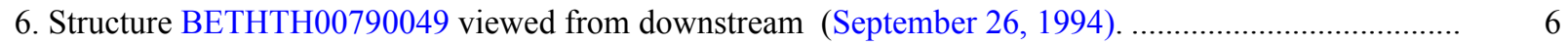

7. Water-surface profiles for the 100- and 500-year discharges at structure BETHTH00790049 on Town Highway 79, crossing Locust Creek, Bethel, Vermont. .

8. Scour elevations for the 100-year discharge at structure BETHTH00790049 on

Town Highway 79, crossing Locust Creek, Bethel, Vermont.

\section{TABLES}

1. Remaining footing/pile depth at abutments for the 100-year discharge at structure

BETHTH00790049 on Town Highway 79, crossing Locust Creek,

Bethel, Vermont

2. Remaining footing/pile depth at abutments for the 500-year discharge at structure

BETHTH00790049 on Town Highway 79, crossing Locust Creek,

Bethel, Vermont..... 


\begin{tabular}{|c|c|c|}
\hline Multiply & By & To obtain \\
\hline \multicolumn{3}{|c|}{ Length } \\
\hline inch (in.) & 25.4 & millimeter (mm) \\
\hline foot $(\mathrm{ft})$ & 0.3048 & meter $(\mathrm{m})$ \\
\hline mile (mi) & 1.609 & kilometer (km) \\
\hline \multicolumn{3}{|c|}{ Slope } \\
\hline foot per mile ( $\mathrm{ft} / \mathrm{mi})$ & 0.1894 & meter per kilometer $(\mathrm{m} / \mathrm{km})$ \\
\hline \multicolumn{3}{|c|}{ Area } \\
\hline square mile $\left(\mathrm{mi}^{2}\right)$ & 2.590 & square kilometer $\left(\mathrm{km}^{2}\right)$ \\
\hline \multicolumn{3}{|c|}{ Volume } \\
\hline cubic foot $\left(\mathrm{ft}^{3}\right)$ & 0.02832 & cubic meter $\left(\mathrm{m}^{3}\right)$ \\
\hline \multicolumn{3}{|c|}{ Velocity and Flow } \\
\hline foot per second $(\mathrm{ft} / \mathrm{s})$ & 0.3048 & meter per second $(\mathrm{m} / \mathrm{s})$ \\
\hline cubic foot per second $\left(\mathrm{ft}^{3} / \mathrm{s}\right)$ & 0.02832 & cubic meter per second $\left(\mathrm{m}^{3} / \mathrm{s}\right.$ \\
\hline cubic foot per second per & 0.01093 & cubic meter per \\
\hline square mile & & second per square \\
\hline$\left[\left(\mathrm{ft}^{3} / \mathrm{s}\right) / \mathrm{mi}^{2}\right]$ & & kilometer $\left[\left(\mathrm{m}^{3} / \mathrm{s}\right) / \mathrm{km}^{2}\right]$ \\
\hline
\end{tabular}

OTHER ABBREVIATIONS

\begin{tabular}{|c|c|c|c|}
\hline $\mathrm{BF}$ & bank full & LWW & left wingwall \\
\hline $\mathrm{cfs}$ & cubic feet per second & $\mathrm{MC}$ & main channel \\
\hline $\mathrm{D}_{50}$ & median diameter of bed material & RAB & right abutment \\
\hline DS & downstream & RABUT & face of right abutment \\
\hline elev. & elevation & $\mathrm{RB}$ & right bank \\
\hline $\mathrm{f} / \mathrm{p}$ & flood plain & ROB & right overbank \\
\hline $\mathrm{ft}^{2}$ & square feet & RWW & right wingwall \\
\hline $\mathrm{ft} / \mathrm{ft}$ & feet per foot & $\mathrm{TH}$ & town highway \\
\hline JCT & junction & UB & under bridge \\
\hline LAB & left abutment & US & upstream \\
\hline LABUT & face of left abutment & USGS & United States Geological Survey \\
\hline LB & left bank & VTAOT & Vermont Agency of Transportation \\
\hline LOB & left overbank & WSPRO & water-surface profile model \\
\hline
\end{tabular}

In this report, the words "right" and "left" refer to directions that would be reported by an observer facing downstream.

Sea level: In this report, "sea level" refers to the National Geodetic Vertical Datum of 1929-- a geodetic datum derived from a general adjustment of the first-order level nets of the United States and Canada, formerly called Sea Level Datum of 1929. 


\title{
LEVEL II SCOUR ANALYSIS FOR BRIDGE 49 (BETHTH00790049) ON TOWN HIGHWAY 79, CROSSING LOCUST CREEK, BETHEL, VERMONT
}

\author{
By Michael A. Ivanoff and Scott A. Olson
}

\section{INTRODUCTION AND SUMMARY OF RESULTS}

This report provides the results of a detailed Level II analysis of scour potential at structure BETHTH00790049 on town highway 79 crossing Locust Creek, Bethel, Vermont (figures $1-8)$. A Level II study is a basic engineering analysis of the site, including a quantitative analysis of stream stability and scour (U.S. Department of Transportation, 1993). A Level I study is included in Appendix $\mathrm{E}$ of this report. A Level I study provides a qualitative geomorphic characterization of the study site. Information on the bridge available from VTAOT files was compiled prior to conducting Level I and Level II analyses and can be found in Appendix D.

The site is in the Green Mountain physiographic province of central Vermont in the town of Bethel. The 24.4- $\mathrm{mi}^{2}$ drainage area is in a predominantly rural and forested basin. In the vicinity of the study site, the banks are forested.

In the study area, Locust Creek has an incised, sinuous channel with a slope of approximately $0.015 \mathrm{ft} / \mathrm{ft}$, an average channel top width of $74 \mathrm{ft}$ and an average channel depth of $6 \mathrm{ft}$. The predominant channel bed material is gravel and cobble $\left(\mathrm{D}_{50}\right.$ is $124 \mathrm{~mm}$ or $0.407 \mathrm{ft}$ ). The geomorphic assessment at the time of the Level I and Level II site visit on September $21 \& 26,1994$, respectively, with a check on $12 / 15 / 94$, indicated that the reach was stable.

The town Highway 79 crossing of Locust Creek is a 55-ft-long, one-lane bridge consisting of one 50-foot concrete span (Vermont Agency of Transportation, written commun., August $24,1994)$. The bridge is supported by vertical, concrete abutments with wingwalls. The channel is skewed approximately 50 degrees to the opening while the opening-skew-toroadway is 45 degrees.

Scour protection measures in place at the site were type-1 stone fill (less than 12 inches diameter) at the upstream right and downstream left road embankment, type-2 stone fill (less than 36 inches diameter) at the upstream left bank, upstream wingwalls, and downstream left wingwall. Additional details describing conditions at the site are included in the Level II Summary and Appendices D and $\mathrm{E}$. 
Scour depths and rock rip-rap sizes were computed using the general guidelines described in Hydraulic Engineering Circular 18 (Richardson and others, 1993).

Total scour at a highway crossing is comprised of three components: 1) long-term degradation; 2) contraction scour (due to accelerated flow caused by a reduction in flow area at a bridge) and; 3) local scour (caused by accelerated flow around piers and abutments). Total scour is the sum of the three components. Equations are available to compute depths for contraction and local scour and a summary of these computed results follow.

Contraction scour for all modelled flows ranged from $0.0 \mathrm{ft}$ to $1.0 \mathrm{ft}$. The worst-case contraction scour occurred at the 100-year discharge. Abutment scour ranged from $10.3 \mathrm{ft}$ to $13.3 \mathrm{ft}$. with the worst-case abutment scour also occurring at the 100-year discharge. Additional information on scour depths and depths to armoring are included in the section titled "Scour Results". Scoured-streambed elevations, based on the calculated depths, are presented in tables 1 and 2. A cross-section of the computed scour at the bridge is presented in figure 8. Scour depths were calculated assuming an infinite depth of erosive material and a homogeneous particle-size distribution.

It is generally accepted that the Froehlich equation (abutment scour) gives "excessively conservative estimates of scour depths" (Richardson and others, 1993, p. 22). Many factors, including historical performance during flood events, the geomorphic assessment, scour protection, and the results of the hydraulic analyses, must be considered to properly assess the validity of abutment scour results. Therefore, scour depths adopted by VTAOT may differ from the computed values documented herein, based on the consideration of additional contributing factors and experienced engineering judgement. 


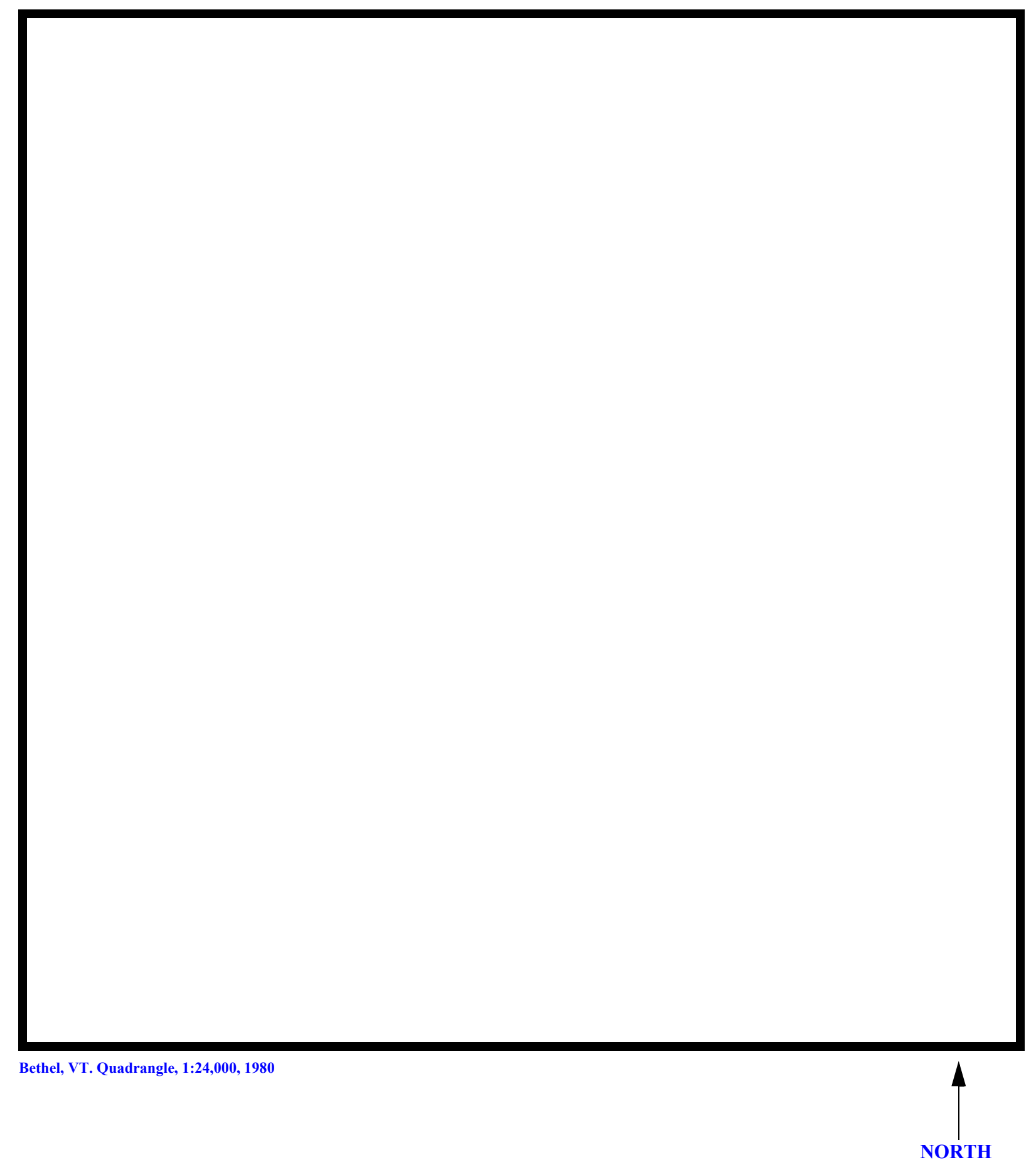

Figure 1. Location of study area on USGS 1:24,000 scale map. 
Figure 2. Location of study area on Vermont Agency of Transportation town highway map. 

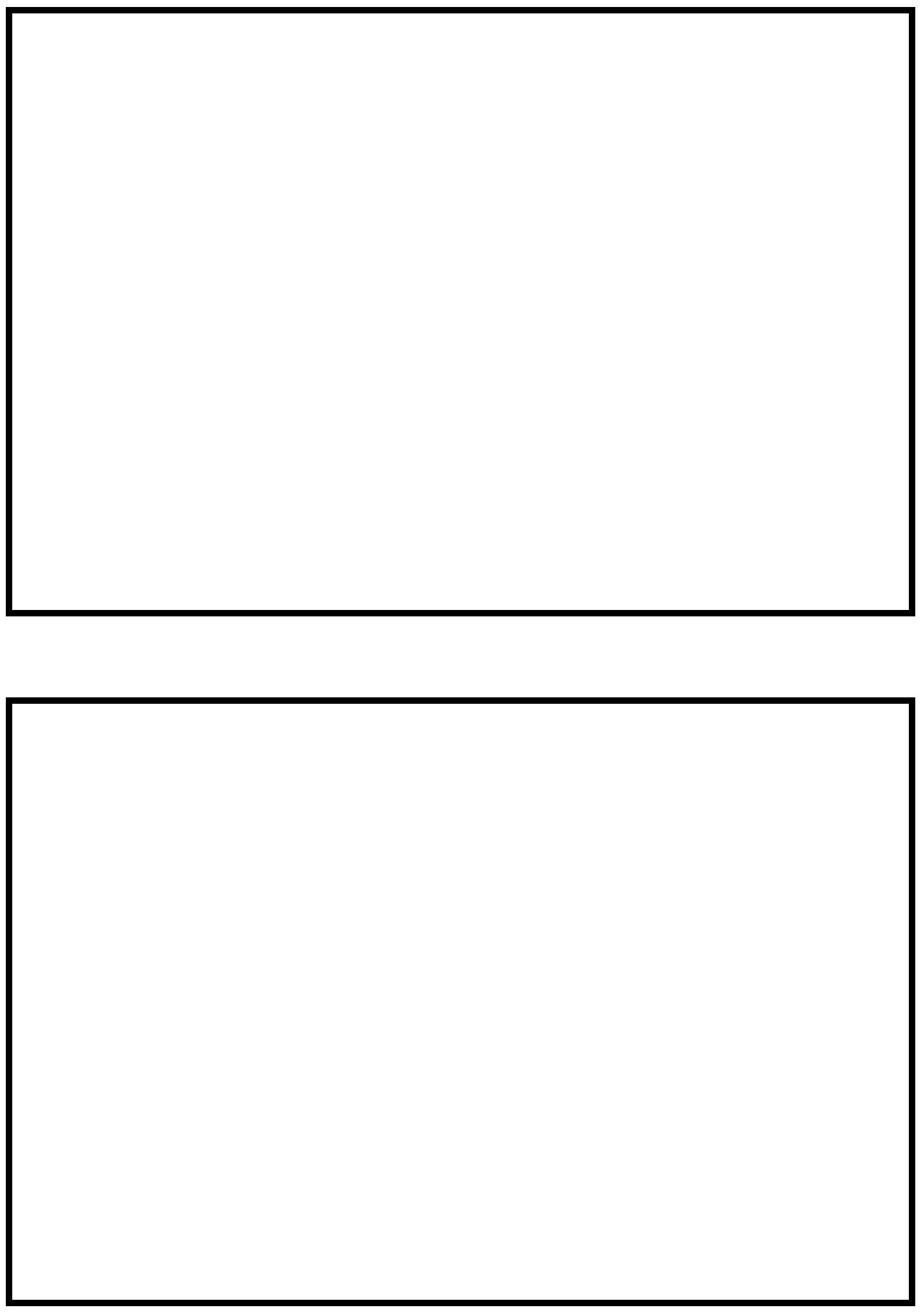

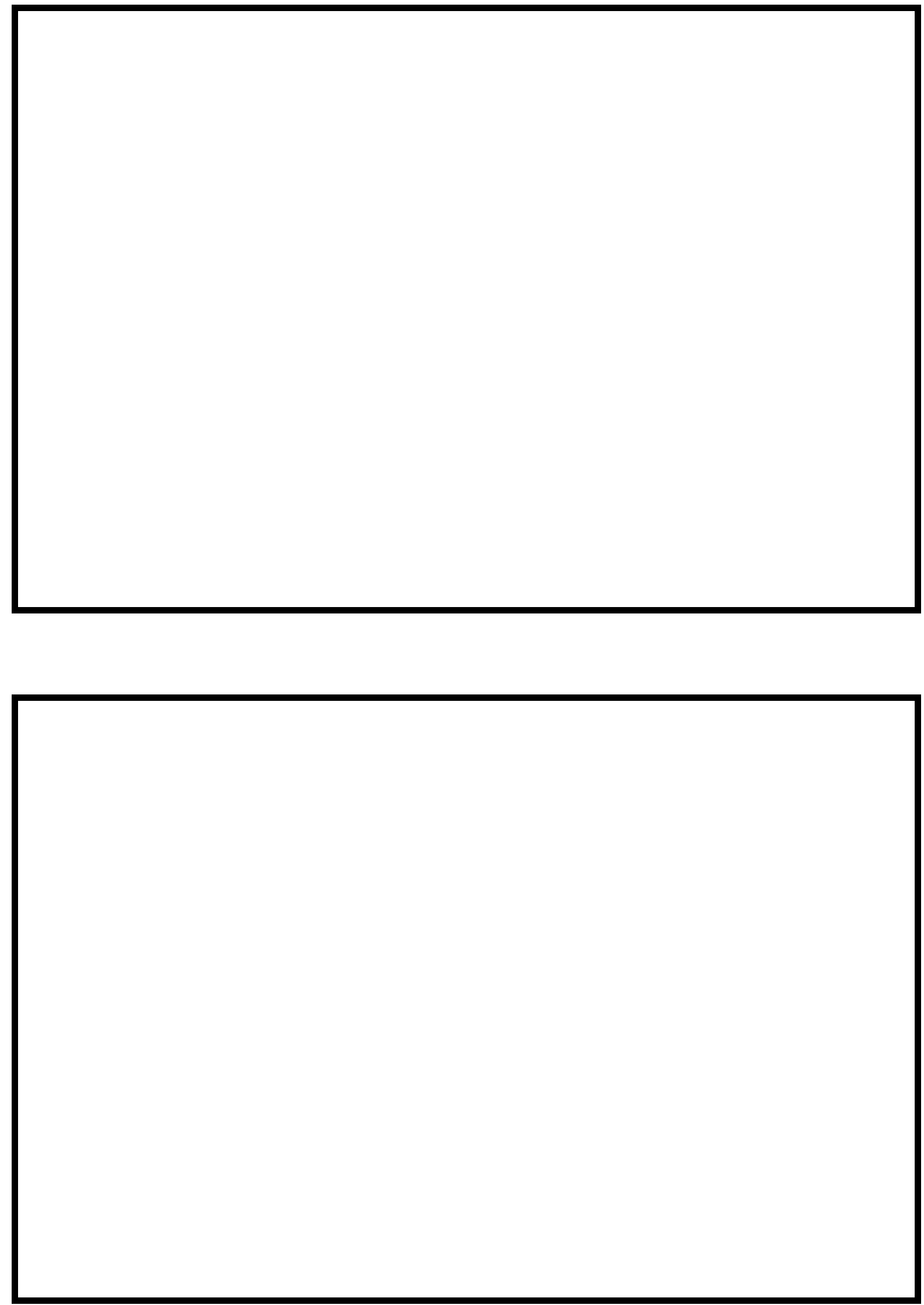


\section{LEVEL II SUMMARY}

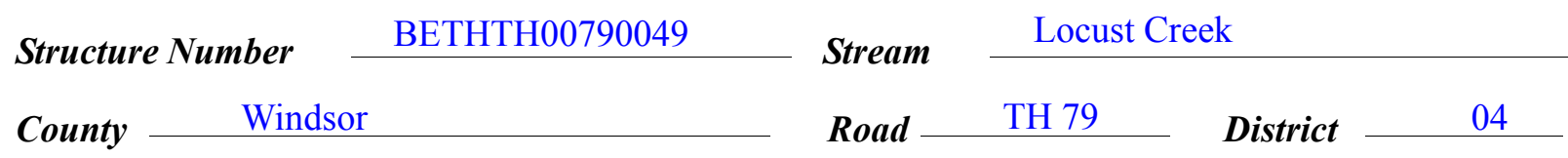

\section{Description of Bridge}

Bridge length $\stackrel{55.0}{ } \boldsymbol{f t} \quad$ Bridge width $\stackrel{50.0}{f t \quad \text { Max span length }} \stackrel{23.4}{\boldsymbol{f t}}$ Alignment of bridge to road (on curve or straight)

Abutment type Concrete

Stone fill on abutment?

$$
\text { No }
$$

\section{Embankment type}

Dato af incnortion Straight

Onsmintinu af atam a fil Type-1, upstream right and downstream left road embankment; type-2,
Sloping

$9 / 21 \& 12 / 15 / 94$ upstream left bank, upstream wingwalls, and downstream left wingwall.

Concrete abutments and wingwalls.

- . . . . . . .

\section{Y}

Is bridge skewed to flood flow according to Y ' survey? Angle

50

Is bridge skewed to flood flow according to Y r survey? Angle

There is a mild bend in the channel into the upstream bridge face and a moderate bend in the channel downstream of the bridge.

Debris accumulation on bridge at time of Level I or Level II site visit:

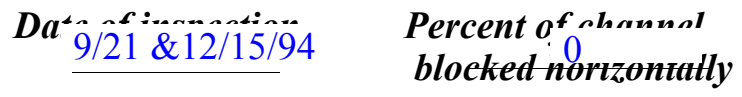

Percent of and anel
blocked verticatty

Level I

9/26/94

Level II

Moderate due to steep banks and forested setting.

\section{Potential for debris}

9/21 \& 12/15/94 -- None

Dosriho anv, fonturos noar ar at tho hridoo that mav affort flow, (includo ahsorvation dato) 


\section{Description of the Geomorphic Setting}

General topography The channel has a flat to slightly irregular narrow flood plain with steep valley walls on both sides.

Geomorphic conditions at bridge site: downstream (DS), upstream (US)

Date of inspection $\quad 9 / 21 \& 12 / 15 / 94$

DS left: $\quad$ Steep channel bank with town highway 79 parallel to the stream

DS right: $\quad$ Steep valley wall

US left: $\quad$ Moderate channel bank slope to a narrow floodplain

US right: $\quad$ Moderate channel bank slope with town highway 79 parallel to the stream

\section{Description of the Channel}

\begin{tabular}{|c|c|c|c|c|c|}
\hline \multirow[b]{2}{*}{ Average top width } & & & \multirow[b]{2}{*}{ Average depth } & 6 & \multirow[b]{2}{*}{$f+$} \\
\hline & $\stackrel{\boldsymbol{f t}}{\text { Gravel / Cobbles }}$ & & & Cobbles & \\
\hline Predominant bed material & & & Bank material & row, incised & \\
\hline channel with only slight sinuosity. & $\cdots$ & " & -. & & \\
\hline
\end{tabular}

$9 / 21 \& 12 / 15 / 94$

Vegetative col forested with town highway 79 parallel to the stream

DS left: $\quad$ forested

DS right: $\quad$ forested with grass on the narrow floodplain near the bridge

US left: $\quad$ forested with town highway 79 parallel to the stream

US right: $\quad \underline{Y}$

Do banks appear stable? 9/21/94 \& 12/15/94-- Assessed as stable however slight fluvial erosion noted on both downstream banks. Also, a cut bank and point bar were noted
date of observatton. downstream. See appendix E for more details.

9/26/94 -- None

Describe any obstructions in channel and date of observation. 


\section{Hydrology}

Drainage area $\quad 24.4 \quad \boldsymbol{m i}^{2}$

Percentage of drainage area in physiographic provinces: (approximate)

Physiographic province

Green Mountain
Percent of drainage area

100

Is drainage area considered rural or urban? Rural Describe any significant urbanization:

None; Area is primarily forested.

Is there a USGS gage on the stream of interest?

No

\section{USGS gage description}

USGS gage number

Gage drainage area

$m i^{2}$

No

Is there a lake/p

$\cdots, \ldots . ., \ldots, \ldots, \ldots$

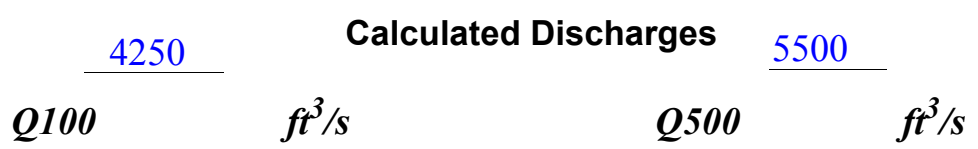

The 100- and 500-year discharges were selected from

a range of values defined by several empirical methods applicable to a watershed of this size in this region (Benson, 1962; Potter, 1957a\&b; Johnson and Tasker, 1974; FHWA, 1983; Talbot,

1887) and a drainage area relationship [(24.4/24.1) to the 0.7 power] with Barnard bridge \#35, also on Locust Creek. Barnard bridge \#35 had flood frequency estimates available from VTAOT (written communication, May 1995). 


\section{Description of the Water-Surface Profile Model (WSPRO) Analysis}

Datum for WSPRO analysis (USGS survey, sea level, VTAOT plans)

USGS survey

Datum tie between USGS survey and VTAOT plans

Add $0.48 \mathrm{ft}$. to USGS survey to

obtain VTAOT plans' datum.

Description of reference marks used to determine USGS datum. $\quad$ RM1 is a chiseled X in a

chiseled square on top of the US end of the left abutment (elev. $499.84 \mathrm{ft}$, arbitrary datum).

RM2 is a chiseled $X$ in a chiseled square on top of the DS end of the left abutment (elev. 499.68

$\mathrm{ft}$, arbitrary datum).

\section{Cross-Sections Used in WSPRO Analysis}

\begin{tabular}{ccll}
\hline${ }^{1}$ Cross-section & $\begin{array}{c}\text { Section } \\
\text { Reference } \\
\text { Distance } \\
\text { (SRD) } \text { in feet }\end{array}$ & $\begin{array}{c}{ }^{2} \text { Cross-section } \\
\text { development }\end{array}$ & \multicolumn{1}{c}{ Comments } \\
\hline EXITX & -58 & 1 & $\begin{array}{l}\text { Exit section } \\
\text { Downstream Full-valley } \\
\text { section (Templated from } \\
\text { EXITX) }\end{array}$ \\
BRIDG & 0 & 2 & $\begin{array}{l}\text { Bridge section } \\
\text { Road Grade section }\end{array}$ \\
RDWAY & 18 & 1 & $\begin{array}{l}\text { Modelled Approach sec- } \\
\text { tion (Templated from } \\
\text { ATEMP) }\end{array}$ \\
ATEMP & 61 & 1 & $\begin{array}{l}\text { Approach section as sur- } \\
\text { veyed (Used as a tem- } \\
\text { plate) }\end{array}$ \\
\hline
\end{tabular}

${ }^{1}$ For location of cross-sections see plan-view sketch included with Level I field form, Appendix E. For more detail on how cross-sections were developed see WSPRO input file. 


\section{Data and Assumptions Used in WSPRO Model}

Hydraulic analyses of the reach were done by use of the Federal Highway Administration's WSPRO step-backwater computer program (Shearman and others, 1986, and

Shearman, 1990). Results of the hydraulic model are presented in the Bridge Hydraulic Summary, Appendix B, and figure 7.

Channel roughness factors (Manning's " $\mathrm{n}$ ") used in the hydraulic model were estimated using field inspections at each cross section following the general guidelines described by Arcement, Jr. and Schneider (1989). Final adjustments to the values were made during the modelling of the reach. Channel " $\mathrm{n}$ " values for the reach ranged from 0.047 to 0.054 .

Normal depth at the exit section (EXITX) was assumed as the starting water surface. This depth was computed by use of the slope-conveyance method outlined in the User's manual for WSPRO (Shearman, 1990). The slope used was $0.015 \mathrm{ft} / \mathrm{ft}$ which was computed from surveyed thalweg points downstream of the bridge.

The surveyed approach section (ATEMP) was moved along the approach channel slope $(0.025 \mathrm{ft} / \mathrm{ft})$ to establish the modelled approach section (APPRO), one bridge length upstream of the upstream face as recommended by Shearman and others (1986). This approach also provides a consistent method for determining scour variables.

The modeled 100 and 500-yr discharges overtop the roadway embankment. The incipient overtopping discharge was determined to be $3020 \mathrm{cfs}$. 


\section{Bridge Hydraulics Summary}

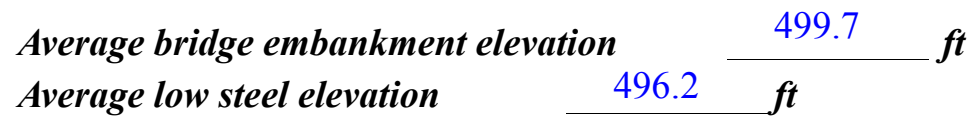

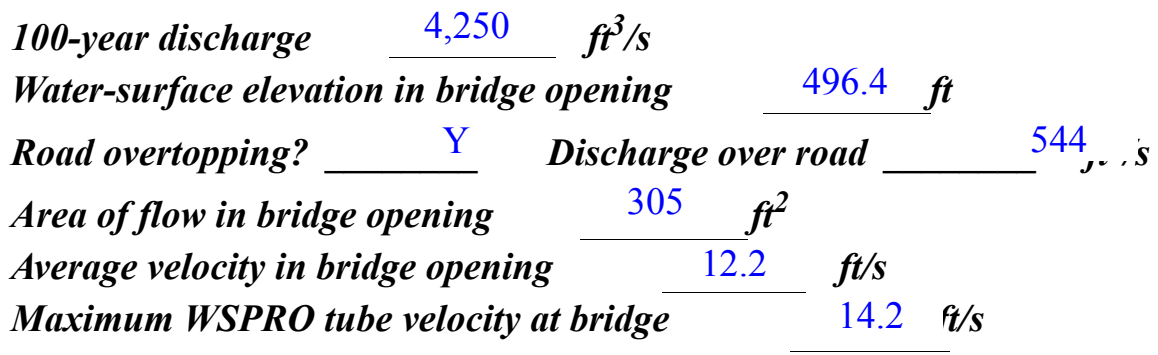

Water-surface elevation at Approach section with bridge Water-surface elevation at Approach section without bridge 499.8 Amount of backwater caused by bridge $2.9 \quad \boldsymbol{i}$

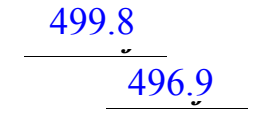

500-year discharge $\quad 5,500 \quad \mathrm{ft}^{3} / \mathrm{s}$

Water-surface elevation in bridge opening $496.4 f t$

Road overtopping? ___ Y Discharge over road __ 1902,36

Area of flow in bridge opening $\quad 305 \quad \mathrm{ft}^{2}$

Average velocity in bridge opening $11.8 \mathrm{ft} / \mathrm{s}$

Maximum WSPRO tube velocity at bridge 13.7 , 's

Water-surface elevation at Approach section with bridge

Water-surface elevation at Approach section without bridge

Amount of backwater caused by bridge 2.6 .

500.6

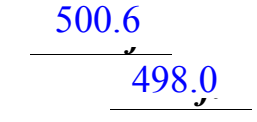

Incipient overtopping discharge $\quad 3,020 \quad \mathrm{ft}^{3} / \mathrm{s}$

Water-surface elevation in bridge opening $496.4 \quad t$

Area of flow in bridge opening

Average velocity in bridge opening

$305 \quad \boldsymbol{f t}^{2}$

Maximum WSPRO tube velocity at bridge

$9.7 \mathrm{ft} / \mathrm{s}$

Water-surface elevation at Approach section with bridge

Water-surface elevation at Approach section without bridge

498.9

Amount of backwater caused by bridge

3.4 it




\section{Scour Analysis Summary Special Conditions or Assumptions Made in Scour Analysis}

Scour depths were computed using the general guidelines described in Hydraulic Engineering Circular 18 (Richardson and others, 1993). Scour depths were calculated assuming an infinite depth of erosive material and a homogeneous particle-size distribution. The results of the scour analysis are presented in tables 1 and 2 and a graph of the scour depths is presented in figure 8.

Contraction scour was computed by use of the Chang pressure-flow contraction scour equation (Richardson and others, 1995, p. 145-146) for the 100-year and 500-year discharges. For each of the modelled discharges, there was orifice flow at the bridge. Contraction scour at bridges with orifice flow is best estimated by use of the Chang pressure-flow scour equation (oral communication, J. Sterling Jones, October 4, 1996). The results of Laursen's clear-water contraction scour (Richardson and others, 1995, p. 35, equation 18) were also computed and can be found in appendix F. For contraction scour computations, the average depth in the contracted section (AREA/TOPWIDTH) is subtracted from the depth of flow computed by the scour equation (Y2) to determine the actual amount of scour.

Abutment scour was computed by use of the Froehlich equation (Richardson and others, 1993, p. 49, equation 24). The Froehlich equation gives "excessively conservative estimates of scour depths" (Richardson and others, 1993, p. 48). Variables for the Froehlich equation include the Froude number of the flow approaching the embankments, the length of the embankment blocking flow, and the depth of flow approaching the embankment less any roadway overtopping.

The length to depth ratio of the embankment blocking flow exceeded 25 in all cases except for left abutment at the incipient roadway overflow discharge. Although the HIRE equation (Richardson and others, 1993 , p. 50, equation 25) is applicable when this ratio exceeds 25 , the results from the HIRE equation were not used. Hydraulic Engineering Circular 18 recommends that the field conditions are similar to the field conditions from which the HIRE equation was derived (Richardson and others, 1993). Since the equation was developed from Army Corp of Engineers' data obtained for spur dikes in the Mississippi River, the HIRE equation was not adopted for the upland $\mathrm{V}$-shaped valley in this study.

The 100-year discharge analysis resulted in the worst case contraction and total scour. Thus, figure 8 only displays the 100 -year scour depths. 


\section{Scour Results}

$$
\text { 100-yr discharge 500-yr discharge }
$$

(Scour depths in feet)

Main channel

Live-bed scour

Clear-water scour

Depth to armoring

Left overbank

Right overbank

Local scour:

Abutment scour

Left abutment

Right abutment

Pier scour

Pier 1

Pier 2

Pier 3
12.8

$13.3-$
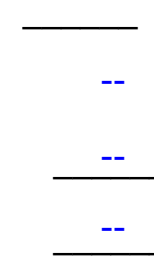

10.3

13.3-

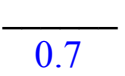

$5.7^{-}$

---
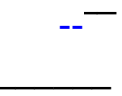

discharge

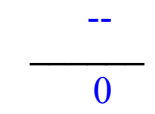

$2.0^{-}$

$--$
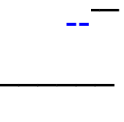

12.8

12.4-

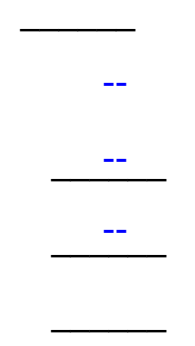

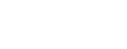
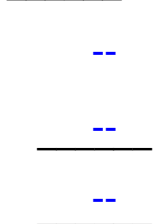

\section{Rock Riprap Sizing}

Incipient overtopping 100-yr discharge 500-yrdischarge discharge

Abutments:

Left abutment

3.5 ( $D_{50}$ in feet)

\begin{tabular}{|c|c|c|}
\hline \multicolumn{3}{|c|}{50 ongeen) } \\
\hline 3.5 & 3.4 & 2.6 \\
\hline 3.5 & 3.4 & 2.6 \\
\hline --- & -- $^{-}$ & -- $^{-}$ \\
\hline -- & -- & -- \\
\hline--- & --- & -- \\
\hline
\end{tabular}




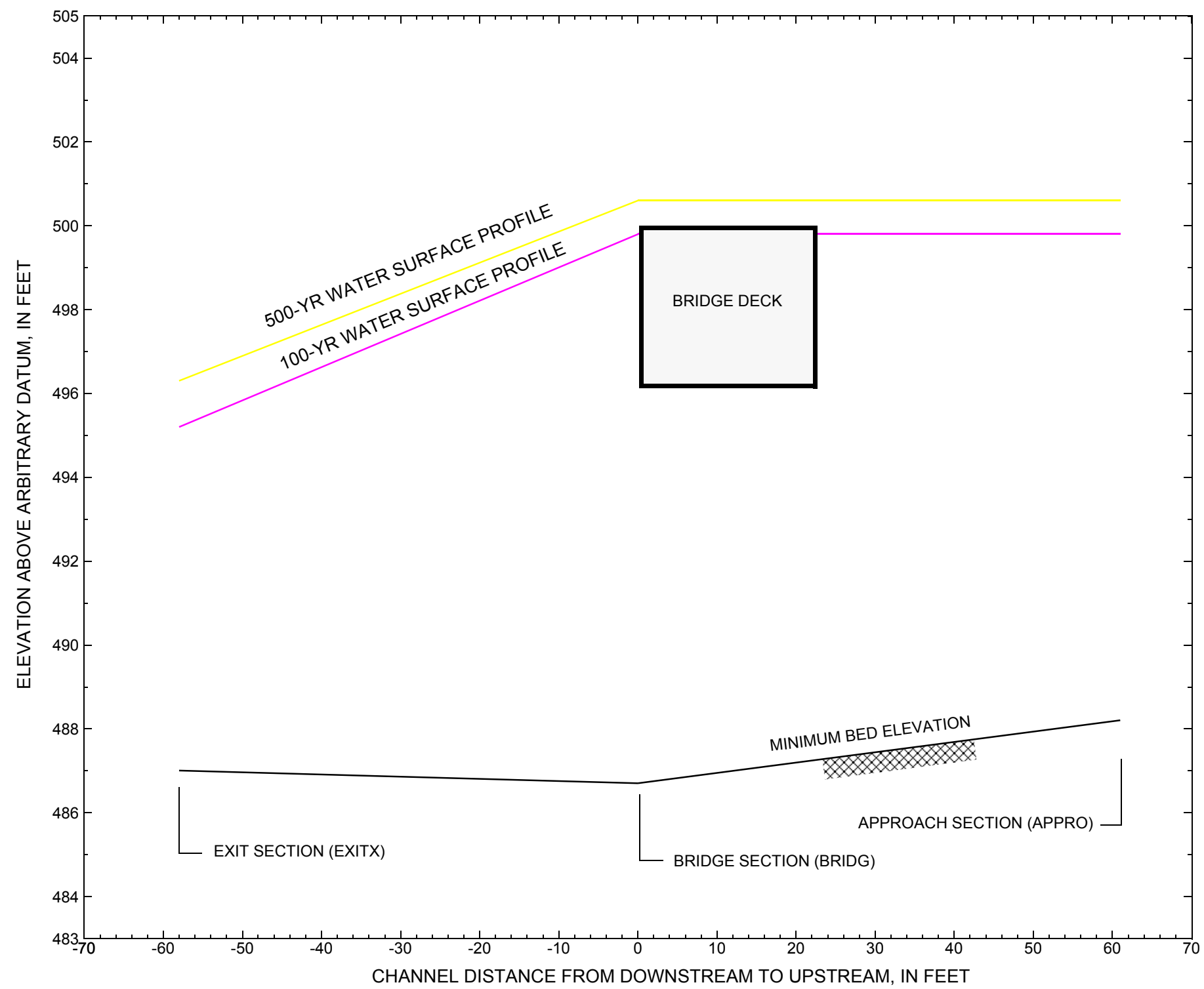

Figure 7. Water-surface profiles for the 100- and 500-yr discharges at structure BETHTH00790049 on town highway 79, crossing Locust Creek, Bethel, Vermont. 


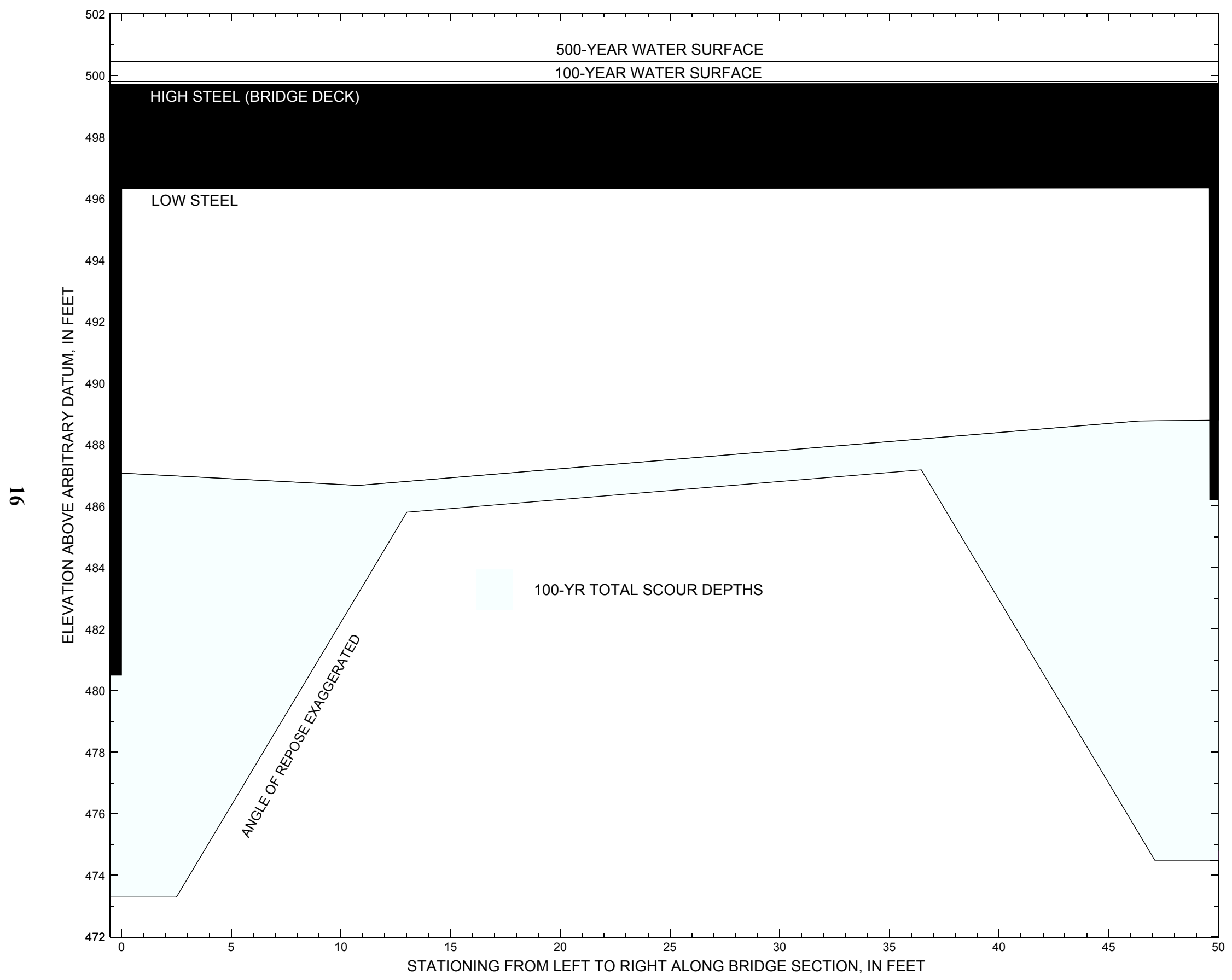

Figure 8. Scour elevations for the 100-year discharge at structure BETHTH00790049 on town highway 79, crossing Locust Creek, Bethel, Vermont. 
Table 1. Remaining footing/pile depth at abutments for the 100-year discharge at structure BETHTH00790049 on Town highway 79, crossing Locust Creek, Bethel, Vermont.

[VTAOT, Vermont Agency of Transportation; --,no data]

\begin{tabular}{|c|c|c|c|c|c|c|c|c|c|c|c|}
\hline Description & Station $^{1}$ & $\begin{array}{l}\text { VTAOT } \\
\text { minimum } \\
\text { low-chord } \\
\text { elevation } \\
\text { (feet) }\end{array}$ & $\begin{array}{l}\text { Surveyed } \\
\text { minimum } \\
\text { low-chord } \\
\text { elevation } \\
\text { (feet) }\end{array}$ & $\begin{array}{l}\text { Bottom of } \\
\text { footing } \\
\text { elevation } \\
\text { (feet) }\end{array}$ & $\begin{array}{l}\text { Channel } \\
\text { elevation at } \\
\text { abutment/ } \\
\text { pier }^{2} \\
\text { (feet) }\end{array}$ & $\begin{array}{l}\text { Contraction } \\
\text { scour depth } \\
\text { (feet) }\end{array}$ & $\begin{array}{l}\text { Abutment } \\
\text { scour } \\
\text { depth } \\
\text { (feet) }\end{array}$ & $\begin{array}{l}\text { Pier } \\
\text { scour } \\
\text { depth } \\
\text { (feet) }\end{array}$ & $\begin{array}{l}\text { Depth of } \\
\text { total scour } \\
\text { (feet) }\end{array}$ & $\begin{array}{c}\text { Elevation of } \\
\text { scour }^{2} \\
\text { (feet) }\end{array}$ & $\begin{array}{c}\text { Remaining } \\
\text { footing/pile } \\
\text { depth } \\
\text { (feet) }\end{array}$ \\
\hline \multicolumn{12}{|c|}{100 -yr. discharge is 4,250 cubic-feet per second } \\
\hline Left abutment & 0.0 & 496.7 & 496.4 & 480.5 & 487.1 & 1.0 & 12.8 & -- & 13.8 & 473.3 & -7 \\
\hline Right abutment & 49.7 & 496.7 & 496.2 & 486.5 & 488.8 & 1.0 & 13.3 & -- & 14.3 & 474.5 & -12 \\
\hline
\end{tabular}

1. Measured along the face of the most constricting side of the bridge.

2. Arbitrary datum for this study.

Table 2. Remaining footing/pile depth at abutments for the 500-year discharge at structure BETHTH00790049 on Town Highway 79, crossing Locust Creek, Bethel, Vermont.

[VTAOT, Vermont Agency of Transportation; --, no data]

\begin{tabular}{|c|c|c|c|c|c|c|c|c|c|c|c|}
\hline Description & Station $^{1}$ & $\begin{array}{l}\text { VTAOT } \\
\text { minimum } \\
\text { low-chord } \\
\text { elevation } \\
\text { (feet) }\end{array}$ & $\begin{array}{l}\text { Surveyed } \\
\text { minimum } \\
\text { low-chord } \\
\text { elevation } \\
\text { (feet) }\end{array}$ & $\begin{array}{l}\text { Bottom of } \\
\text { footing } \\
\text { elevation } \\
\text { (feet) }\end{array}$ & $\begin{array}{c}\text { Channel } \\
\text { elevation at } \\
\text { abutment/ } \\
\text { pier }^{2} \\
\text { (feet) }\end{array}$ & $\begin{array}{l}\text { Contraction } \\
\text { scour depth } \\
\text { (feet) }\end{array}$ & $\begin{array}{l}\text { Abutment } \\
\text { scour } \\
\text { depth } \\
\text { (feet) }\end{array}$ & $\begin{array}{l}\text { Pier } \\
\text { scour } \\
\text { depth } \\
\text { (feet) }\end{array}$ & $\begin{array}{l}\text { Depth of } \\
\text { total scour } \\
\text { (feet) }\end{array}$ & $\begin{array}{c}\text { Elevation of } \\
\text { scour }^{2} \\
\text { (feet) }\end{array}$ & $\begin{array}{c}\text { Remaining } \\
\text { footing/pile } \\
\text { depth } \\
\text { (feet) }\end{array}$ \\
\hline \multicolumn{12}{|c|}{500 -yr. discharge is 5,500 cubic-feet per second } \\
\hline Left abutment & 0.0 & 496.7 & 496.4 & 480.5 & 487.1 & 0.7 & 10.3 & -- & 11.0 & 476.1 & -4 \\
\hline Right abutment & 49.7 & 496.7 & 496.2 & 486.5 & 488.8 & 0.7 & 13.3 & -- & 14.0 & 474.8 & -12 \\
\hline
\end{tabular}

1. Measured along the face of the most constricting side of the bridge.

2. Arbitrary datum for this study. 


\section{SELECTED REFERENCES}

Arcement, G.J., Jr., and Schneider, V.R., 1989, Guide for selecting Manning's roughness coefficients for natural channels and flood plains: U.S. Geological Survey Water-Supply Paper 2339, 38 p.

Barnes, H.H., Jr., 1967, Roughness characteristics of natural channels: U.S. Geological Survey Water-Supply Paper 1849, 213 p.

Benson, M.A., 1962, Factors influencing the occurrence of floods in a humid region of diverse terrain: U.S. Geological Survey WaterSupply Paper 1580-B, 64 p.

Brown, S.A. and Clyde, E.S., 1989, Design of riprap revetment: Federal Highway Administration Hydraulic Engineering Circular No. 11, Publication FHWA-IP-89-016, 156 p.

Federal Highway Administration, 1983, Runoff estimates for small watersheds and development of sound design: Federal Highway Administration Report FHWA-RD-77-158

Froehlich, D.C., 1989, Local scour at bridge abutments in Ports, M.A., ed., Hydraulic Engineering--Proceedings of the 1989 National Conference on Hydraulic Engineering: New York, American Society of Civil Engineers, p. 13-18.

Hayes, D.C.,1993, Site selection and collection of bridge-scour data in Delaware, Maryland, and Virginia: U.S. Geological Survey Water-Resources Investigation Report 93-4017, 23 p.

Johnson, C.G. and Tasker, G.D.,1974, Progress report on flood magnitude and frequency of Vermont streams: U.S. Geological Survey Open-File Report 74-130, 37 p.

Laursen, E.M., 1960, Scour at bridge crossings: Journal of the Hydraulics Division, American Society of Civil Engineers, v. 86, no. HY2, p. 39-53.

Potter, W. D., 1957a, Peak rates of runoff in the Adirondack, White Mountains, and Maine woods area, Bureau of Public Roads

Potter, W. D., 1957b, Peak rates of runoff in the New England Hill and Lowland area, Bureau of Public Roads

Richardson, E.V., and Davis, S.R., 1995, Evaluating scour at bridges: Federal Highway Administration Hydraulic Engineering Circular No. 18, Publication FHWA-IP-90-017, 204 p.

Richardson, E.V., Harrison, L.J., Richardson, J.R., and Davis, S.R., 1993, Evaluating scour at bridges: Federal Highway Administration Hydraulic Engineering Circular No. 18, Publication FHWA-IP-90-017, 131 p.

Richardson, E.V., Simons, D.B., and Julien, P.Y., 1990, Highways in the river environment: Federal Highway Administration Publication FHWA-HI-90-016.

Ritter, D.F., 1984, Process Geomorphology: W.C. Brown Co., Debuque, Iowa, 603 p.

Shearman, J.O., 1990, User's manual for WSPRO--a computer model for water surface profile computations: Federal Highway Administration Publication FHWA-IP-89-027, 187 p.

Shearman, J.O., Kirby, W.H., Schneider, V.R., and Flippo, H.N., 1986, Bridge waterways analysis model; research report: Federal Highway Administration Publication FHWA-RD-86-108, 112 p.

Talbot, A.N., 1887, The determination of water-way for bridges and culverts.

U.S. Department of Transportation, 1993, Stream stability and scour at highway bridges, Participant Workbook: Federal Highway Administration Publication FHWA HI-91-011.

U.S. Geological Survey, 1980, Bethel, Vermont 7.5 Minute Series quadrangle map: U.S. Geological Survey Topographic Maps, Scale $1: 24,000$. 
APPENDIX A:

\section{WSPRO INPUT FILE}


WSPRO INPUT FILE

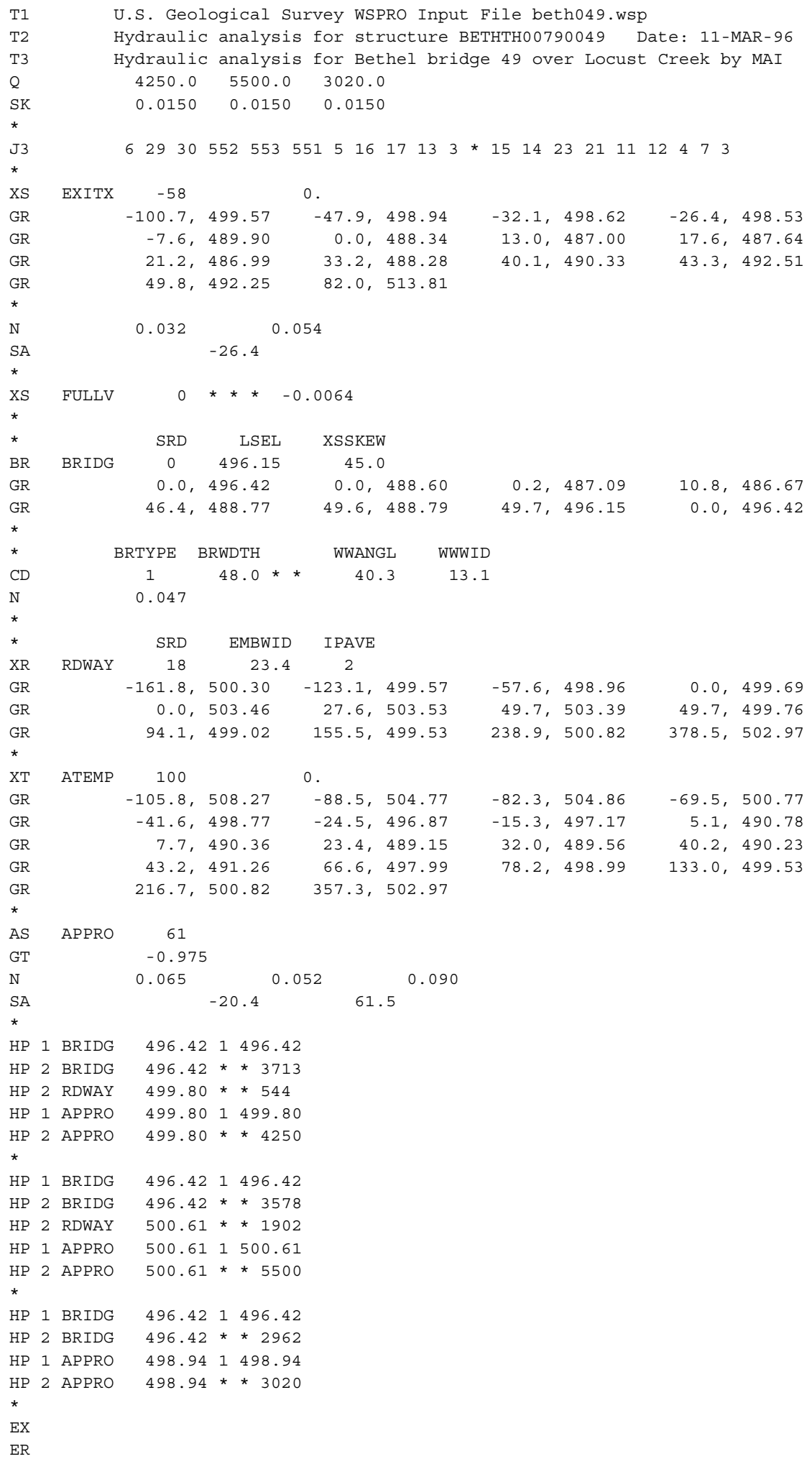


APPENDIX B:

\section{WSPRO OUTPUT FILE}


WSPRO FEDERAL HIGHWAY ADMINISTRATION - U. S. GEOLOGICAL SURVEY

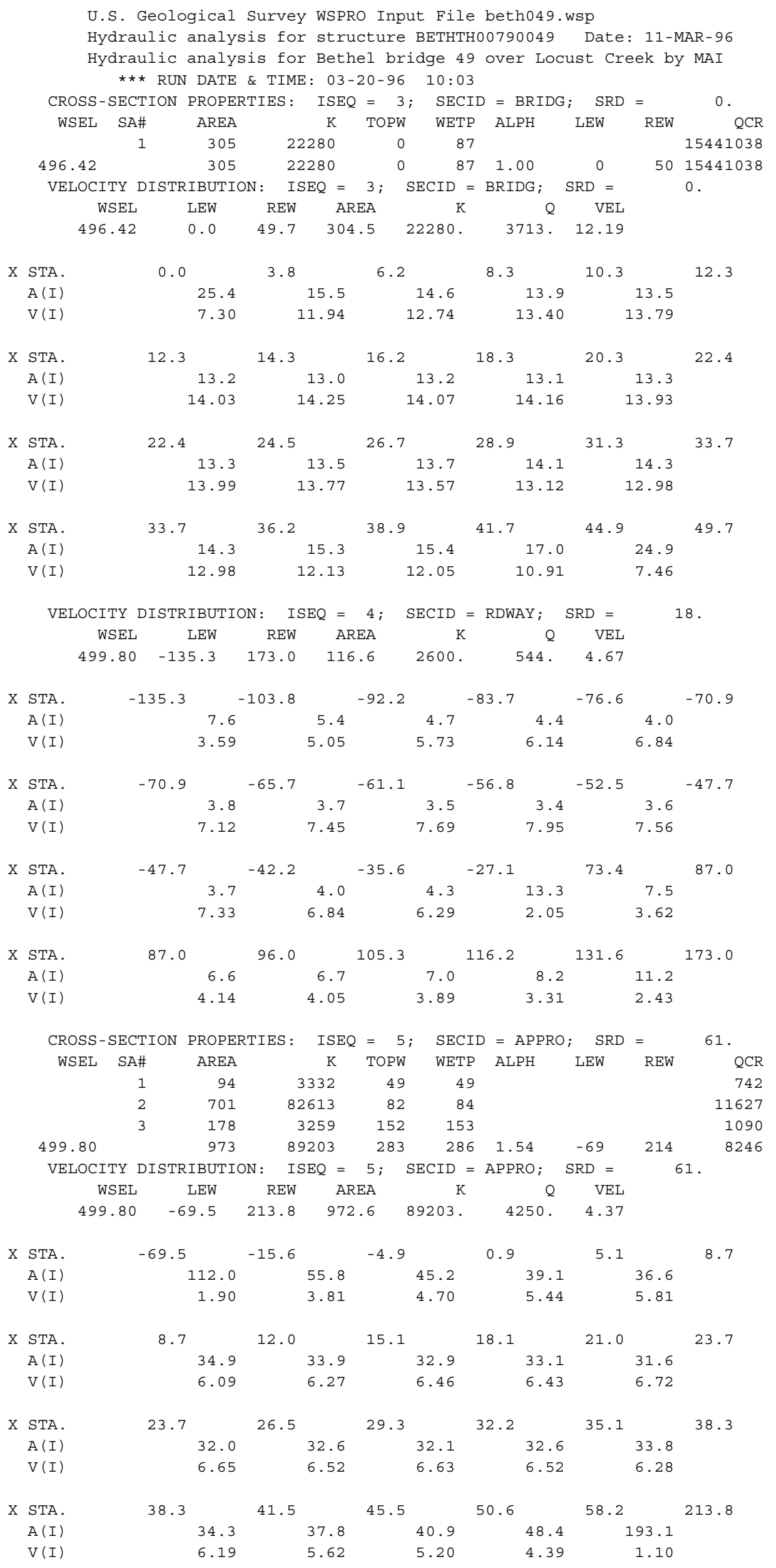


WSPRO OUTPUT FILE (continued)

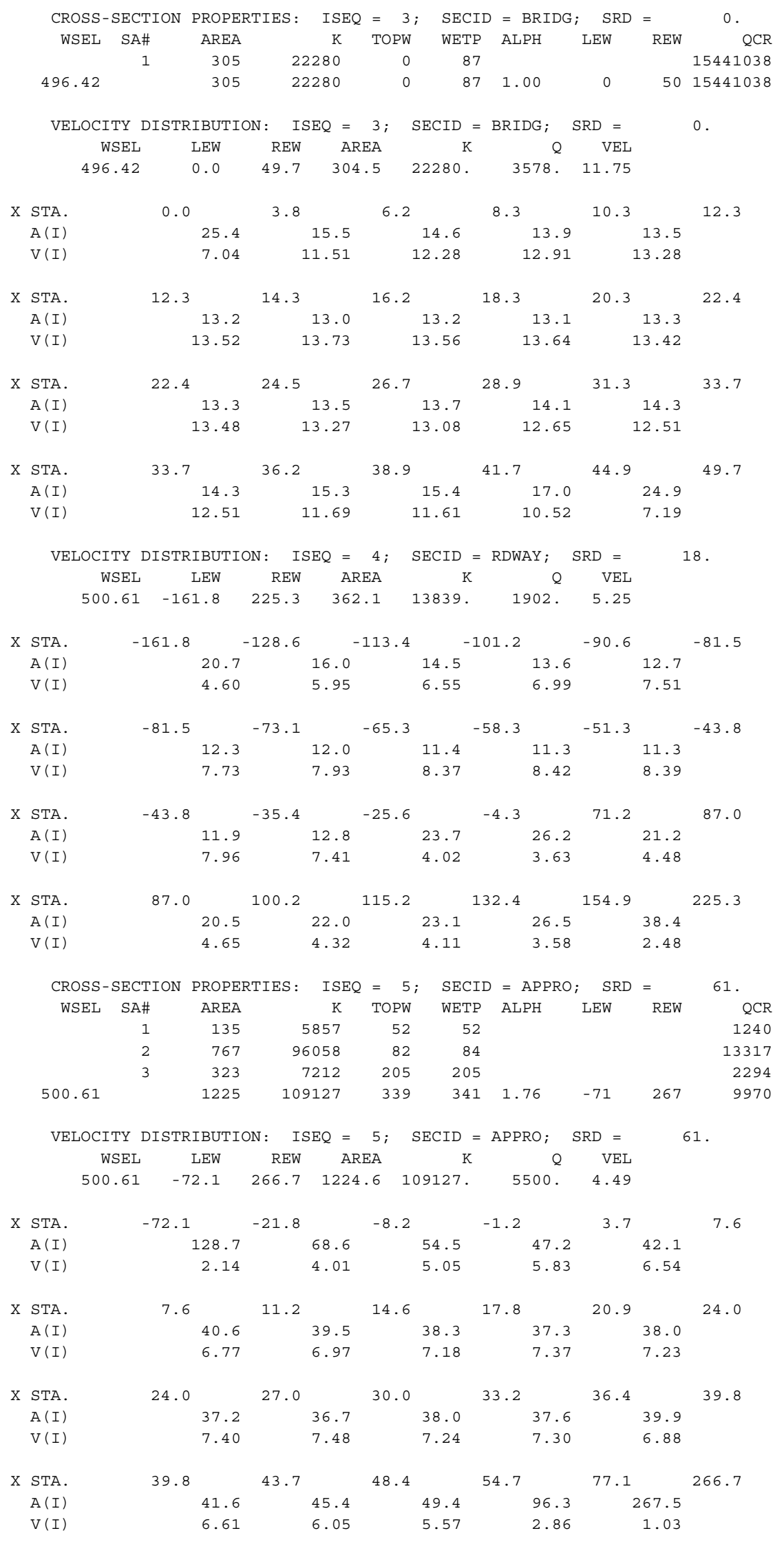




\section{WSPRO OUTPUT FILE (continued)}

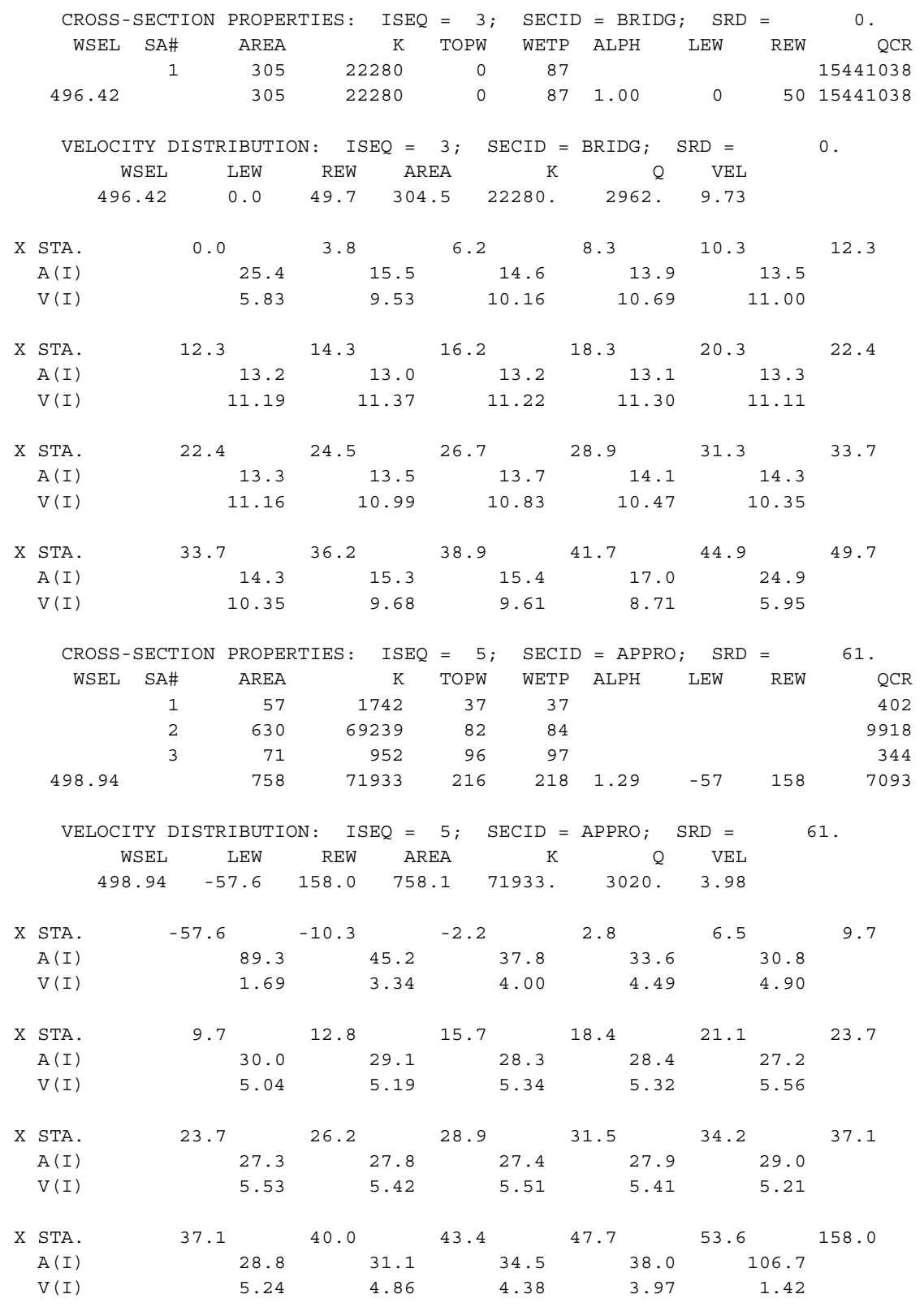


WSPRO OUTPUT FILE (continued)

$\begin{array}{rrrrrrrrrr}\text { XSID : CODE } & \text { SRDL } & \text { LEW } & \text { AREA } & \text { VHD } & \text { HF } & \text { EGL } & \text { CRWS } & \text { Q } & \text { WSEL } \\ \text { SRD } & \text { FLEN } & \text { REW } & \text { K } & \text { ALPH } & \text { HO } & \text { ERR } & \text { FR\# } & \text { VEL } & \\ & & & & & & & & & \\ \text { EXITX : XS } & * * * * * * & -18 & 411 & 1.66 & * * * * * & 496.91 & 494.26 & 4250 & 495.25 \\ -57 & * * * * * * & 54 & 34683 & 1.00 * * * * * * * * * * * & 0.77 & 10.33 & \end{array}$

$==135$ CONVEYANCE RATIO OUTSIDE OF RECOMMENDED LIMITS.

"FULLV" KRATIO $=1.47$

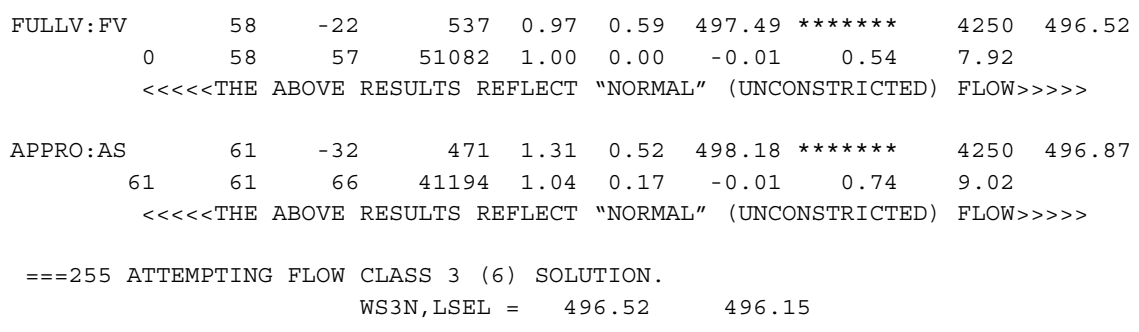


WSPRO OUTPUT FILE (continued)

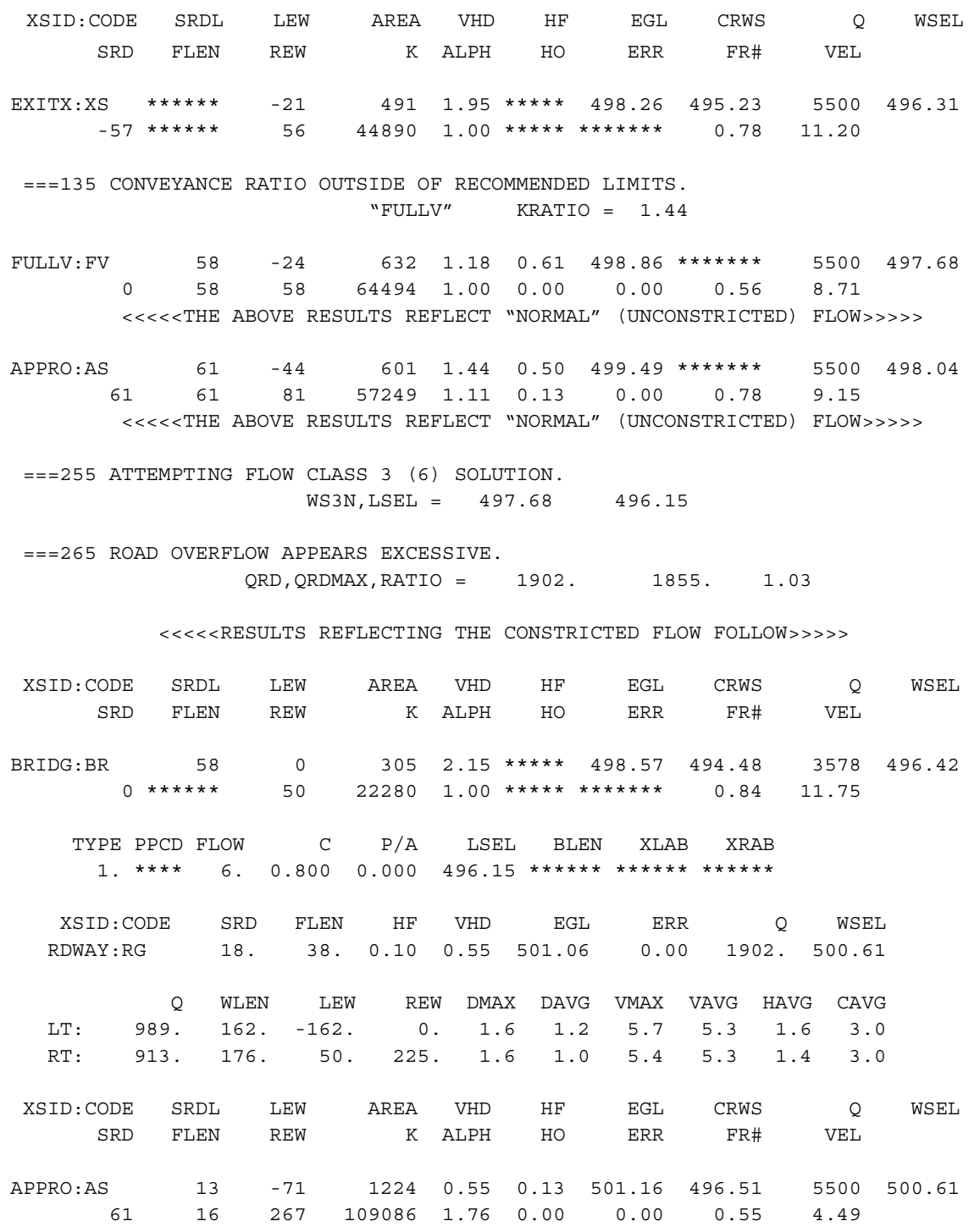

FIRST USER DEFINED TABLE.

$\begin{array}{lrrrrrrrr}\text { XSID : CODE } & \text { SRD } & \text { LEW } & \text { REW } & Q & \text { K } & \text { AREA } & \text { VEL } & \text { WSEL } \\ \text { EXITX : XS } & -58 . & -22 . & 56 . & 5500 . & 44890 . & 491 . & 11.20 & 496.31 \\ \text { FULLV : FV } & 0 . & -25 . & 58 . & 5500 . & 64494 . & 632 . & 8.71 & 497.68 \\ \text { BRIDG : BR } & 0 . & 0 . & 50 . & 3578 . & 22280 . & 305 . & 11.75 & 496.42 \\ \text { RDWAY : RG } & 18 . * * * * * * & 989 . & 1902 . * * * * * * * * * * * * * * * & 2.00 & 500.61 \\ \text { APPRO : AS } & 61 . & -72 . & 267 . & 5500 . & 109086 . & 1224 . & 4.49 & 500.61\end{array}$

SECOND USER DEFINED TABLE.

\begin{tabular}{|c|c|c|c|c|c|c|c|c|}
\hline XSID : CODE & CRWS & FR\# & YMIN & YMAX & $\mathrm{HF}$ & VHD & EGL & WSEL \\
\hline EXITX:XS & 495.23 & 0.78 & 486.99 & $513.81 *$ & 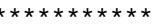 & 1.95 & 498.26 & 496.31 \\
\hline FULLV : FV & 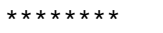 & 0.56 & 486.62 & 513.44 & 0.610 .00 & 1.18 & 498.86 & 497.68 \\
\hline BRIDG : BR & 494.48 & 0.84 & 486.67 & 496.42 * & $\star \star * \star * \star *$ & 2.15 & 498.57 & 496.42 \\
\hline RDWAY : RG & 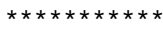 & $\star * \star * *$ & 498.96 & 503.53 & $0.10 * * * * * *$ & 0.55 & 501.06 & 500.61 \\
\hline APPRO:AS & 496.51 & 0.55 & 488.17 & 507.29 & $0.13 \quad 0.00$ & 0.55 & 501.16 & 500.61 \\
\hline
\end{tabular}


WSPRO OUTPUT FILE (continued)

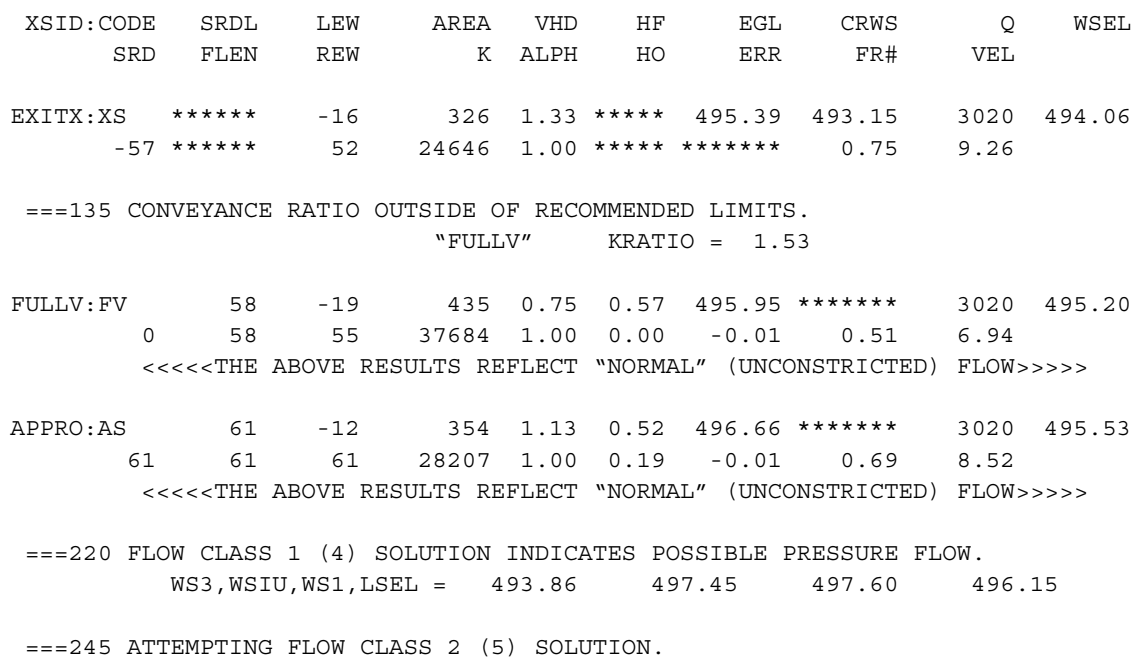

\begin{tabular}{|c|c|c|c|c|c|c|c|c|c|}
\hline XSID : CODE & CRWS & FR\# & YMIN & YMAX & $\mathrm{HF}$ & $\mathrm{HO}$ & VHD & EGL & WSEL \\
\hline EXITX:XS & 493.15 & 0.75 & 486.99 & $513.81 *$ & $* * * * * *$ & $\star \star \star \star \star *$ & 1.33 & 495.39 & 494.06 \\
\hline FULLV : FV & 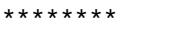 & 0.51 & 486.62 & 513.44 & 0.57 & 0.00 & 0.75 & 495.95 & 495.20 \\
\hline BRIDG : BR & 493.67 & 0.69 & 486.67 & 496.42 * & $* * * * * *$ & $\star \star \star \star * *$ & 1.47 & 497.89 & 496.42 \\
\hline RDWAY : RG & 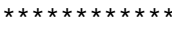 & $\star \star \star \star \star *$ & 498.96 & 503.53 * & $* * \star * \star *$ & $* \star \star * \star *$ & 0.11 & 501.81 * & $\star * * * * *$ \\
\hline APPRO : AS & 494.28 & 0.43 & 488.17 & 507.29 & 0.09 & 1.15 & 0.32 & 499.26 & 498.94 \\
\hline
\end{tabular}




\section{APPENDIX C:}

\section{BED-MATERIAL PARTICAL-SIZE DISTRIBUTION}




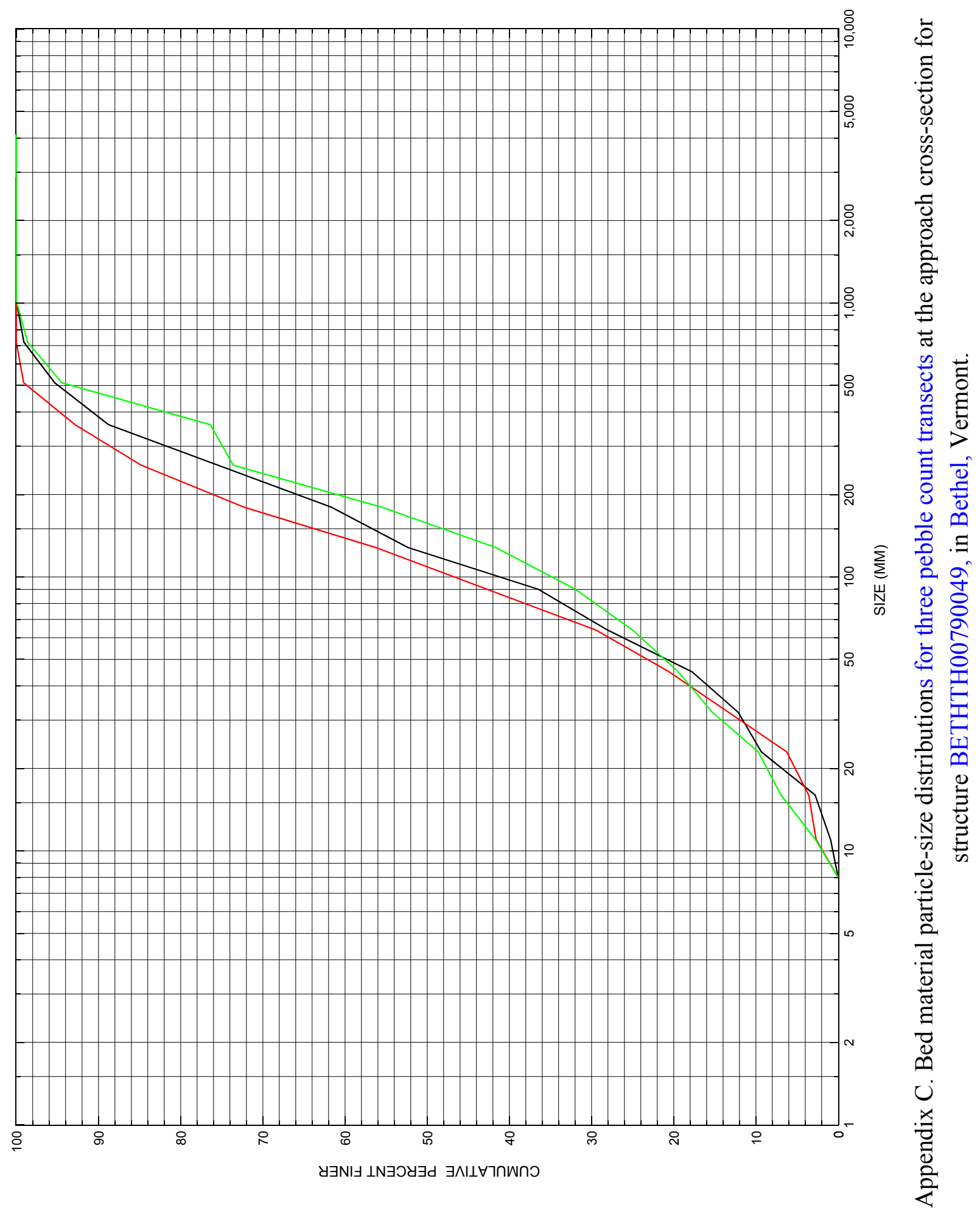




\section{APPENDIX D: \\ HISTORICAL DATA FORM}

